JEBII

\title{
THE NATURE OF RISK IN ISLAMIC FINANCIAL INSTITUTIONS
}

\section{Sifat Risiko dalam Institusi Keuangan Islam}

\author{
Putri Reno Kemala Sari ${ }^{1}$ \\ ${ }^{1}$ Faculty of Management and Business, Universitas Technology Sumbawa \\ Email: putrirenoks@yahoo.com
}

\begin{abstract}
ABSTRAK
Lembaga keuangan Islam adalah bisnis yang berisiko dan beberapa faktor risiko telah diidentifikasi penting untuk memastikan bahwa posisi lembaga keuangan Islam tetap terjaga di tengah persaingan ketat di industri ini. Kelangsungan hidup dan keberhasilan sebuah organisasi keuangan sangat bergantung pada efisiensi pengelolaan risiko. Lebih penting lagi, manajemen risiko yang baik sangat relevan dalam memberikan tingkat pengembalian yang lebih baik kepada para pemangku kepentingan. Selain itu, lembaga keuangan yang mengelola risiko dengan hati-hati merupakan ciri khas untuk menghindari tekanan finansial yang bisa mengakibatkan krisis keuangan. Penelitian ini bertujuan untuk mengetahui jenis risiko di Lembaga keuangan Islam. Penelitian ini menggunakan metode kualitatif untuk mengumpulkan dan menganalisis data melalui observasi langsung dan studi dokumentasi. Temuan dalam penelitian ini menawarkan interpretasi baru terhadap sumber utama yang secara signifikan memperkenalkan bukti dan temuan baru yang akan bermanfaat bagi pemain di industri Islam, termasuk pembuat kebijakan dan regulator untuk mengembangkan, meningkatkan dan memperbaiki manajemen risiko. Selanjutnya, penelitian ini berharap dapat memberikan kontribusi dalam hal strategi rekomendasi untuk memperkuat dan mengetahui risiko di lembaga keuangan Islam sehingga dapat meningkatkan daya saing keseluruhan di industri keuangan Islam
\end{abstract}

Keywords : Jenis risiko, Lembaga Keuangan Islam, Manajemen Resiko

\begin{abstract}
Islamic financial institutions are a risky business and several risk factors have been identified as critical to ensure that the Islamic financial institutions position remain intact amid the intense competition in the industry. The survival and success of a financial organization depends critically on the efficiency of managing risks. More importantly, good risk management is highly relevant in providing better return to the stakeholders. In addition, prudent risk management by financial institutions is the hallmark to avoid financial distress that could lead to financial crisis. This research aims to identify the types of risk in Islamic Financial Institutions. This research is using qualitative method to collect and analyze the data through direct observation and documentation study. The findings in this study offers a new interpretation of the primary sources that significantly introduce substantial new evidence and findings that would be beneficial for players in the Islamic industry, including policymakers and regulators to develop, enhance and improve the Risk Management. Furthermore, the study hopes to contribute in terms of recommendation strategy to strengthen and knowing the risk of the Islamic Financial Institutions so as to increase the overall competitiveness in the Islamic Financial Industry.
\end{abstract}

Keywords : Nature of risk, Islamic Financial Institutions, Risk Management

\section{Introduction}

Islamic financial institutions were established three decades ago as an alternative to conventional financial institutions mainly to provide Shari'ah compliant investments, financing, and trading opportunities. The Islamic financial institutions school of thought can be investigated from 1500 B.C with the advent of Islam and teaching of Quran. But it is gaining global importance and emerging as an alternative to interest based economic system ${ }^{1}$. The Islamic financial institutions industry has grown

'Satar,Abdul (2011). Risk Management in Islamic financial institutions 
impressively during a short period of time. In the early 1960 's, Islamic financial institutions and finance sector witnessed a steady growth in its different aspects such as size, complexity of the transactions, and internal processes. It has been estimated that the sector is witnessing a $15 \%$ annual growth rate $(10 \% \text { of which is in the gulf region })^{2}$.

Islamic financial institutions now exists in more than 75 countries accounting for more than $250 \$$ billion in assets ${ }^{3}$. The Islamic financial institutions industry is growing rapidly and gaining importance in the global financial scenario. Islamic financial institutions are control some 40-50 percent of Muslim savings by 2009-2010. Assets of the Islamic financial institutions worldwide are currently estimated at US\$750 Billion, registering an unprecedented growth of 20-30 percent in the last ten years ${ }^{4}$.

One of the major aspects that should be taken miv consideration in dealing with Islamic finance is risk management and then risk mitigation. With respect to financial institutions, risk management, as defined by finance literature, is the practice of creating economic value in a firm by using financial instruments to manage the exposure to different risks. Being involved in the intermediation process, risk management is as important to the Islamic financial institutions as it is to the conventional financial institution ${ }^{5}$. A growing literature suggestion that risk management is even more challenging for the Islamic financial institutions compared to the conventional counterpart. Islamic financial institutions industry is in general different from conventional Islamic financial institutions due to several core features.

Risk management activities themselves can expose Islamic financial institutions to risk $^{6}$. For example, the newer risks that arise from additional products, the more time the risk management department will need to study them and to find ways to mitigate them, leading to a greater risk arising from the opportunity cost of not introducing the product at the desired time.

Risk is variability and volatility of unpredictable out comes. Financial institutions face number of risks these can be classified in different ways such as business risks, operational risks and financial risks. As far as the business risks are concerned they arise from the nature of business while financial risks arise from the possible loss in financial market due

\footnotetext{
${ }^{2}$ ISRA. (2011). Islamic Financial System Principles and Operation.

${ }^{3}$ Zawaya business information. http://www.zawya.com/

${ }^{4}$ Asian bankers. (2008).

${ }^{5}$ A risk management standard. Association of Insurance and

Risk Managers UK,http://www.airmic.com/, 2002.
}

to movement in financial variables ${ }^{7}$. Financial risks include market risk and credit risk, while non financial risks are operational risk, regulatory risk and legal risk. Having a full furnished risk profile in view, the risk management normally demands some step for each type of risk included in the profile.

This research is using qualitative method to achieve the objectives of the research. The researcher humbly claims that this study is indeed original and the data are collected by several techniques such as direct observation, and documentation study. Results of the investigation were analyzed by researcher to conclude the main ideas on the basis of primary data and the reviewed literature.

\section{Nature and Risks faced by Islamic Financial Institution}

Some Islamic Financial Institution was slightly affected by the current financial crises. Islamic Financial Institution exhibit higher level of financial risk than Conventional Financial Institution do for a number of reasons ${ }^{8}$. First, as most of the investments of an Islamic Financial Institution are on a profitand-loss-sharing basis, the variation of the rate of ultimate return to the Islamic Financial Institution of its investment is greater. This argument is, however, not fully acceptable since most Islamic Financial Institution, currently, are predominated by nonliquid form. Third, Islamic Financial Institution are heavily exposed to the risk exchange rate movement since they are not allowed to hedge their positions. Finally, Islamic Financial Institution are more exposed to the risks arising from changes in government fiscal and monetary policies than Conventional Financial Institution. The common risk faced by Islamic Financial Institution are given as under.

Averroës (Ibn Rushad) ${ }^{9}$, a Maliki author said :'Gharar in transaction of sale causes the buyer to suffer a loss and is the result of lack of knowledge concerning either the price or the subject matter. Gharar is averted if both the price and the subject matter are proved to be in existence at the time the transaction is concluded, if their qualities are known and their quantities determined, if the parties have control over them so as to ensure that the exchange takes place, finally, if any term of time involved is precisely determined'.

\footnotetext{
${ }^{6}$ The Financial Services Round Table. (1999)

${ }^{7}$ Jorion,Khoury.(2006).Financial Risk Management

${ }^{8}$ Beikos, 1997. Capital Intellegence.

${ }^{9}$ Sanusi,2012, “Al Gharar Uncertainty, Risk Taking, Speculation

In Islamic Law"
} 
Hassan ${ }^{10}$ identifies three types of risks from the Islamic Perspective. First, is the essential risk that is inherent in all business transactions. This business risk is necessary and must be undertaken to reap the associated reward or profit. Two Shariah legal maxim associating returns to essential risks form the basis of Islamic economic transaction. The first maxim state "the detriment is as a return for the benefit (النغرم بـالغنـم)" This maxim attaches "the entitlement of gain" to the "responsibility of loss". This maxim is usually used to propose the preference for profit-and-loss-sharing (PLS) financing instruments. The second maxim is derived from the Prophetic saying "الخرج بالضمن" stating "the benefits of a thing is a return for the liability for loss from that thing" 12 . The maxim asserts that the party enjoying the full benefits of an asset or object should be bear the risk of ownership.

Second is the prohibited risk in the form of excessive The Arabic word الغرر. . Teans uncertainty and risk. الغرر. is not precisely defined as Riba where it is absolutely prohibited. According to Arsalan Tariq ${ }^{13}$, الغرر.is any transaction whose consequences are hidden. A minor part of الـنـرر. may refer to consumer protection in modern securities law. الغرر. is present when an essential element of a transaction is missing such as the exact price or the ability to deliver the product. الـغرر. is considered to be the second major prohibition in Islamic Financial Institution and finance. Generally, الغرر. relates to the ambiguity and or ignorance of either the terms of the contract or in the object of the contract. Thus, a sale can be void due to الغرر. , due to risks of existence and taking position of the object of sale on one hand and uncertainty of the quantity, quality, price and time of payment on the other. Ibn Taymiyyah ${ }^{14}$ provides another perspective of forbidden الغرر. by equating it to activities leading to evils and unjustified devouring of people's wealth as in the case of gambling. Thus, transaction having gambling-like features are forbidden due to excessive الـغـرر. This prohibition aims to protect both small and large investors from future risks arising from uncertainty and speculation. An example of الغرر.is trading what you do not actually own. A contemporary example would be buying a house where the price or the specifications will be determined in the future.

The final form of risk identified by Hassan is the permissible risk that does not fall in the above two

\footnotetext{
${ }^{10}$ Hassan,2009. "Basic Sharia Principles Govering Risk Management" Paper submitted for Harverd

${ }^{11}$ Majallah,2001. Being an English translation of Majallah alAhkam al-'Adliyyah and a complete code on Islamic Civil Law. Pp 87

${ }^{12}$ Majallah,2001. Being an English translation of Majallah alAhkam al-'Adliyyah and a complete code on Islamic Civil Law. Pp 85
}

categories. Examples of these risks can be operational risks, liquidity risks,etc. These risks can be either be accepted or avoided.

\section{Credit Risk}

Credit risk is perhaps the most serious risk faced by financial institutions. It arises from the inability of a debtor to settle the debt on time in accordance with agreed terms. This can give rise to not only a liquidity crisis but also a decline in the quality of the banks' assets.

A number of factors determine the level of credit risk faced by conventional banks. Some of the most important of these are: rating of the counter-parties, nature of the legal system, quality of collateral, maturity of credit facility, size of banking and trading books, utilization of credit derivatives, and internal control systems. Islamic banks face some additional risks as a result of their PLS and salesbased debt-creating operations, the differences of opinion among the fuqah $\bar{a}^{, 15}$, and their inability to use credit derivatives and reschedule debts on the basis of a higher mark-up rate. It is, therefore, necessary for Senior Management of Islamic banks as well as their supervisory authorities to have a clear understanding of all these risks and to pay due attention to them in their evaluation of the bank's condition. It is also necessary for them to give due attention to changes in economic and other circumstances which lead to deterioration in the ability of the banks' counterparties to meet their obligations on time.

Given all these different sources of credit risk, it would be necessary for the Board of Directors of Islamic financial institutions to adopt the following measures: ${ }^{16}$

(One) Create an appropriate credit risk culture in the bank by approving and periodically reviewing the strategy of the bank for this purpose and making Senior Management responsible for developing policies and procedures for identifying, measuring, monitoring and controlling credit risk in keeping with the Board's overall goals and strategy.

(Two) Establish sound and well-defined credit granting criteria that would help determine the

\footnotetext{
${ }^{13}$ Arsalan Tariq, A. (2004). Managing Financial Risks of Sukuk Structures.UK: Loughborough Univercity.

${ }^{14}$ Taymiyyah,Ibn. 1998. Majmu' al-Fatawa.Al-Mansurah:Dar alWafa'

15 For a discussion of these see Chapra and Khan, Pp.71-83 and Pp.53-6. See also Khan and Ahmed, 2001.

16 See BCBS, September 2000, for details.
} 
credit-worthiness of the borrower or counterparty; the purpose and structure of the credit, and the source of repayment; his or her repayment history; current capacity to repay; and the terms and conditions on which credit could be granted.

(Three) Set proper procedures for amendment, renewal, refinancing and extension of existing credits.

(Four) Maintain an appropriate information system that would enable the Management to administer, measure and monitor the credit risk and to develop an internal risk rating system that is in harmony with the nature, size, and complexity of the bank's activities.

(Five) Take into consideration potential future changes in economic conditions when assessing individual credits.

(Six) Establish a system of independent assessment of the bank's credit risk management process, review this assessment itself, and ensure that Senior Management takes appropriate action to manage problem credits.

Supervisors also have a crucial role to play in credit risk management by banks. They must set prudential limits to restrict bank exposure to single borrowers or groups of connected counterparties as well as to different sectors of business. ${ }^{17}$ They must also conduct an independent evaluation of the bank's strategies, policies, procedures and practices related to the granting of credit and the ongoing management of the bank's portfolio.

\section{Market Risk}

According to IFSB (2005) $)^{18}$ market risk is defined as losses in on-and-off balance sheet positions arising from movements in the market prices, i.e. function in values in tradable, marketable, or leasable assets such as "Sukuk". Market risk may also arise from the movement in the market interest rate, though Islamic Financial Institution do not deal with it ${ }^{19}$. In fact, Islamic financial institutions use a benchmark rate in order to price the different financial instruments. Saunders and Cornett ${ }^{20}$ define market risk as "the risk associated with the uncertainty of a financial institution's earnings on its trading portfolio". This inevitably could be caused by changes in market conditions such as interest rates, market volatility,

\footnotetext{
${ }^{17}$ A cooperative Islamic bank failed in India when real estate prices

collapsed because it had an excessively large exposure to realstate.

${ }^{18}$ Islamic Financial Services Board. Guiding Principles of Risk

Management For Institutions (other than Insurance Institutions)

Offering Only Islamic Financial Services.
}

market liquidity or the price of an asset. Market risk is more prevalent when the assets and liabilities are actively traded in the short-term rather than holding them for long-term investment funding or hedging purposes.

\section{Liquidity Risk}

Liquidity risk arises from the imbalance in cash in lows and out flows. "Islamic Financial Institution have different obligations such as the requirements to repay current account holders on demand, to provide committed funds in "مشــاركة"transactions, and to make available cash lows for expenses or profit payment". Liquidity risk in Islamic Financial Institution rises when operating requirement become insufficient which lead to liquidity risk and Islamic Financial Institution fails to meet its liabilities when fall due. Islamic Financial Institution may face liquidity risk due to difficulties in obtaining cash at reasonable of Islamic Financial Institution. This liquidity risk is due to the unavailability of lender of the last resort facilities. Liquidity is critical issue because Islamic Financial Institution are required to compensate for expected and unexpected variations in Islamic Financial Institution balance sheet and also they should provide fund for growth ${ }^{21}$. Liquidity represent Islamic Financial Institution ability to payback obligations and fulfills and the demand of funding in the loan and investment portfolio ${ }^{22}$.

Liquidity risk arises when there is an unexpected decline in the bank's net cash flow and the bank is unable to raise resources at a reasonable cost in a Sharī'ah compatible manner. This would make it difficult for the bank to meet its obligations as they become due, or to fund new opportunities for profitable business.

The mismatch between their deposits and their loans and investments exposes all commercial banks, irrespective of whether they are conventional or Islamic, to liquidity problems. The danger is that the bank may maintain too much liquidity to avoid getting into this difficulty. While a high ratio of liquidity would satisfy the bank's safety consideration, it would hurt its profitability objective. Creating a right balance between the two objectives of safety and profitability is thus the crux of the liquidity management problem.

\footnotetext{
${ }^{19}$ Archer, 2008.Risk Management: An Analysis of Issues in Islamic

Financial Industry.

${ }^{20}$ Saunders, A. and Cornett, M. (2006), Financial Institutions Management: A Risk Management Approach, McGraw-Hill, Irwin.

${ }^{21}$ Iqbal and Mirrakhor,2007.

${ }^{22}$ Iqbal and Hennie, 2008
} 
The liquidity risk faced by Islamic banks seems to be low at present because of the excess liquidity that they generally tend to maintain. ${ }^{23}$ Two of the primary reasons for this are: the non-availability of adequate Shari'ah-compatible investment opportunities and the difficulty of raising liquidity in a Shari' 'ah compatible manner. Nevertheless, a number of factors may lead to liquidity risks in the future. First, most of these banks generally tend to have a larger share of current accounts in their resources than their conventional counterpart.

Second, there is a fiqhi restriction on the sale of debts, which constitute a major part of their assets. If they are unable to sell these debts, it may not be possible for them to arrange liquidity when they face a liquidity crunch. Third, due to the slow development of Islamic financial instruments, Islamic banks are not able to raise new funds quickly from the markets. The non-existence of an Islamic inter-bank money market tends to make this problem a little more difficult. Fourth, the Lender of Last Resort (LLR) facility is also not available at present except on the basis of interest. Nevertheless, Islamic banks have so far not faced any serious liquidity problems. This should hopefully continue in the future because the drawbacks indicated above are not insurmountable and will hopefully get resolved in the future as a result of the facilities that are now in the process of being created with the cooperation of banks themselves, the central banks, and the IDB.

This takes us to the question of what should the banks do for the effective management of their liquidity? Some measures that need to be considered for adoption are:

(One) The banks should try not to depend on a few large depositors. They should rather try to mobilize their deposits from as large a cross-section of depositors as possible. Moreover, they should also try to diversify their sources of deposits in terms of both regions and economic activity. Their success in realizing this goal would depend on their size and sophistication as well as the nature and complexity of their activities. It would be helpful if the Islamic banks are public limited companies with branches in different parts of the country having diversified economic activities.

(Two) The maturities of their loans and investments should be staggered in such a way that there is an adequate positive cash flow every day. This would be difficult to realize unless up-to-date cash flow information is available to all concerned departments and there is a coordination between their activities in such a way that maintenance of

\footnotetext{
${ }^{23}$ Iqbal, 2001, P.14.
}

optimum liquidity is ensured. All information systems should be streamlined for measuring, monitoring, controlling and reporting liquidity. Fortunately, recent technical and financial innovations have made it possible for banks to do so.

(Three) The existence of a deposit insurance system can help greatly in avoiding bank runs resulting from rumours or shocks and thereby minimize sudden deposit withdrawals.

(Four) The banks should also have in place a contingency plan to fall back upon in case of liquidity shortage and should also make mutual institutional arrangements to enable them to overcome such a shortage. This is, fortunately, in the process of being done.

(Five) The bank's Liquidity Management Committee should involve all members of Senior Management in monitoring and controlling liquidity. It should also set up an internal controls system to ensure that there is proper coordination and no laxity in the management of liquidity.

\section{Operational Risk}

There are differences of opinion on the definition of operational risk, which is considered by the BCBS to be a subset of 'other risks'. ${ }^{24}$ Other risks have been defined by the BCBS to include all risks other than credit, liquidity and interest rate risks, which have already been discussed.

These other risks arise from a number of sources. One of the most important of these is the breakdown in internal controls and corporate governance. Such breakdowns can lead to financial losses through error, self-dealing, fraud, or failure to perform an obligation on time in an efficient manner. It may also cause the interest of the bank to be compromised in some other ways, for example, by its dealers, lending officers or other staff exceeding their authority or conducting business in an unethical or highly risky manner. Operational risk arising from the breakdown of internal controls and corporate governance can also lead to shortfalls in the bank's net income or cash flow as compared with that accepted or targeted, and thus create problems for management. Operational risk may also arise from failure of technology, erosion in reputation, or noncompliance with regulatory standards. They may also arise from man-made disasters like fires and accidents or natural disasters like earthquakes and floods.

In addition to these risks, Islamic banks also face substantial fiqh-related risks arising from the nonstandardized nature of some Islamic banking

\footnotetext{
${ }^{24}$ See BCBS, December 2001
} 
products. Moreover, an efficient and prompt Shari 'ah litigation system is not in place, and banks as well as supervisory staff are not well-oriented in the knowledge of fiqh. The Shari 'ah supervisors are also not well-versed in the implications of modern risk management concepts. This has had the effect of depriving Islamic banks of some genuine risk management tools and systems which may not necessarily be in conflict with the Sharī'ah. However, some of these difficulties are bound to be resolved with the passage of time with the continued evolution of the system and the resolution of fiqhi issues.

In the past, banks relied primarily on internal controls and internal and external audit to manage operational risks. However, recently there has been an emergence of specific structures, tools and processes aimed at managing operational risks. These have made it possible to apply the same kind of rigour to the identification, measurement, monitoring and control of operational risks as is done in the case of credit, liquidity and interest rate risks. It would be necessary to develop an appropriate risk management culture in the bank, make sufficient disclosures to enable the management as well as the depositors and shareholders to assess their operational risk exposure and the quality of the bank's operational risk management. To ensure that banks make a serious effort to manage operational risks, banking supervisors should conduct an independent evaluation of the banks' strategies, policies and procedures to ensure that the banks have an effective system in place to identify, measure, monitor and control operational risks.

\section{Equity Investment Risk}

According to IFSB ${ }^{25}$ equity investment risk arises from entering into a partnership for the purpose of undertaking or participating in a particular financing or general business activity as described in the contract, in which the financier shares in the business risk. The partner's quality, financial history and reputation must be considered by Islamic Financial Institution in addition to the type of the business activities. "مضـاربة" and "مرابحة" are examples of tools, which maybe exposed to equity investment risk. This type of risk may be considered unique to

\footnotetext{
${ }^{25}$ Islamic Financial Services Board. Guiding Principles of Risk Management For Institutions (other than Insurance Institutions)
}

Islamic Financial Institution due to the nature of the Islamic financial instruments.

\section{Interest Rate Risk}

Interest rate risk is also one of the most serious risks faced by conventional financial institutions. It arises from the exposure of their financial position to adverse movements in interest rates. It is, nevertheless, not possible for them to avoid the taking of this risk because it is a normal part of their business, in the same way as the taking of price risk is a normal part of non-bank business. The crux of business is to buy goods and services at a lower price and to sell them at a higher price. The risk arises from fluctuations in both purchase and sale prices due to reasons over which the business has no control. If the surplus between the two prices is positive in spite of these fluctuations, the business may be able to recover all its expenses and also make a profit, provided that the surplus is adequately large.

Since the price paid and received by conventional banks for their primary job of borrowing and lending is interest, managing interest rate risk effectively is crucially important for increasing their profitability as well as shareholder value. While the taking of interest rate risk is unavoidable for banks, it would not be prudent to let the risk cross a certain limit, because excessive interest rate risk may pose a significant threat to their earning and assets base. Changes in interest rates affect not only their interest-sensitive income and expenses but also the underlying value of their assets, liabilities and offbalance sheet instruments. Accordingly, they are expected to try to develop an effective risk management strategy that would help them maintain the interest rate risk within prudent limits so as to ensure not only the safety and soundness of the bank itself but also the stability of the financial system as a whole.

It may be argued here that, since Islamic banks do not deal in interest, there is no question of their being exposed to the interest rate risk. It would be naive to assume this because Islamic banks operate in a financial environment which is dominated by conventional financial institutions, and interest rate changes are bound to affect their earnings as well as assets value. This is because, in sharp contrast with the PLS modes of financing, all the sales-based modes (murābahah, ijārah, salam and istisna ") involve a mark-up or a pre-determined rate of return and a predominant part of their financing at present

Offering Only Islamic Financial Services 
consists of these modes. The banks would have been able to minimize the centripetal force of interestbased conventional financial system if a profitrelated benchmark for this mark-up were available. Unfortunately, this is not the case and may not be so until the PLS system has captured a substantial share of the financial market in Muslim countries.

In the absence of such a profit-related rate, Islamic banks are constrained to use the London Inter-bank Offer Rate (LIBOR) as a benchmark in their financing operations. This link with LIBOR automatically exposes their income and expenditure flows as well as the value of their assets to the interest rate risk. A rise in LIBOR will lead to a rise in the mark-up and, in turn, to a payment of higher profits to future depositors compared with those received by them from users of their medium- and long-term funds. In addition to affecting their earnings and expenses, changes in interest rates will also change the present value of their future cash flows and thereby affect the present value of their assets, liabilities and balance sheet instruments. The risk becomes a little more magnified in the case of Islamic banks because no agreement has yet been reached among the fuqahā' on the permissibility of using derivatives (futures, forwards, and options) to manage their interest rate and exchange rate risks. It has, therefore, not yet become possible for Islamic banks to design Sharī'ah compatible substitutes for the instruments that are used by conventional banks for this purpose. ${ }^{26}$

\section{Legal Risk}

Given the different nature of financial contracts, Islamic Financial Institution face risk related to their documentation and enforcement. As there are no standard form of contracts for various financial instruments, Islamic Financial Institution prepare these according to their understanding of the Shariah, the local laws, and their needs and concern. Lack of standardized contracts along with the fact that there are no litigation systems to resolve problems associated with enforceability of contracts by the counterparty increases the legal risks associated with the Islamic Financial Institution contractual agreements.

\section{Shariah Compliance Risk}

As most depositors and investors use Islamic Financial Institution due to their Islamic character, financial institutions must ensure that all their activities conform to the principles and values of Islam. This would require contacts and all necessary

\footnotetext{
26 See Chapra and Khan, 2000; and Khan and Ahmed, 2001
} for a more detailed discussion of this subject. supporting documentations including the legal papers, forms and processes to be shariahcompliant. After the product is launched in the market, there is need to ensure that the procedures and processes are implemented in accordance with approved shariah guidelines. Other operational issues including treatments of interest based calculations, discounting, early and late payments, defaults, etc. must also follow the guidelines provided by the shariah supervisor board.

\section{Conclusion}

Risk management underscores the fact that the survival of an organization depends heavily on its capabilities to anticipate and prepare for the change rather than just waiting for the change and react to it. The objective of risk management is not to prohibit or prevent risk taking activity, but to ensure that the risks are consciously taken with full knowledge, clear purpose and understanding so that it can be measured and mitigated. It also prevents Institutions from suffering unacceptable loss causing Institutions to fail or materially damage its competitive position. There may not be one-size-fits-all risk management module for all the Islamic financial institutions to be made applicable uniformly. Balancing risk and return is not an easy task as risk is subjective and not quantifiable whereas return is objective and measurable. As in the international practice, a committee approach may be adopted to manage various risks. In Islamic Financial Institutions the nature of risk such as, credit risk, liquidiy risk, market risk, operational risk, equity investment risk, interest rate risk, legal risk and Shariah compliance risk.

\section{Bibliography}

Al-Qur'an al-Kareem

A risk management standard. 2002. Association of Insurance and Risk Managers. UK. http://www.airmic.com/.

Archer, S. and Haron, A. 2008. Operational Risk Exposures of Islamic Banks, inArcher, S. and Karim, R. A. A. 2007, Islamic Finance: the Regulatory Challenge: John Wiley \& Son (Asia) Pte Ltd.

Arsalan Tariq, A. 2004. Managing Financial Risks of Sukuk Structures. UK: Southborough University

Basel Committee on Banking Supervision (BCBS). 1999. Principle for the Management of Credit Risk. Consultative Paper, Basel Committee on Banking Supervision, July 1999. 
Chapra, Muhammad Umer 2008. The Islamic Vision of Development in the Light of Maqasid al- Shari'ah.

Hassan. 2009. Basic Sharia Principles Govering Risk Management. Paper submitted for Harvard LSE Workshop on Risk Management, London School of Economics. 26 February 2009

Ibn Taymiyyah. 1998. Majmu' al-Fatawa. AlMansurah: Dar al-Wafa'.

IFSB. 2005. Guiding Principle of Risk Management for Institution (Other Than Insurance Institutions) Offering Only Islamic Financial Services. Islamic Financial Board.

Iqbal, Zamir and Mirakhor, Abbas. 2007. An Introduction to Islamic Finance: Theory and Practice. Chichester: John Wiley \& Sons, Inc. Islamic Financial Services Board. (2005a). Guiding Principles of Risk Management for Institutions (Other than Insurance Institutions) Offering Only Islamic Financial Services. Available at $<$ http://www.ifsb.org $>$

Iqbal, $\mathrm{M}$ and Khan,T. 2008. Financial Engineering and Islamic Contracts. New York: Palgrave Macmillan.
ISRA. 2011. Islamic Financial System Principles and Operation. Malaysia: Pearson.

Islamic Financial Industry. Occasional Paper No. 5. Jeddah: Islamic Research and Training Institute, Islamic Development Bank.

Khan, Tariqullah. 2004. Risk Management in Islamic Banking: A Conceptual Framework. Paper presented at Distance Learning Lecture, organised by Islamic Research and Training Institute, Islamic Development Bank.

Majallat-al Ahkam. (001. The Majelle (1876): Being an English Translation of Majallah al-Ahkam al-Adliyyahand a Complete Code on Islamic Civil Law. Translated by C.R.Tyer, D.G. Dementriades \& Ismail Haqqi Efendi. Kuala Lumpur

Sattar, Abdul. 2010. Risk Management in Islamic Banking. USA: Lambert Academic Publishing

Saunders, A. and Cornett, M. (2006). Financial Institutions Management: A Risk Management Approach, McGraw-Hill, Irwin.

Zawya business information. http://www.zawya.com/ 